Vol. 7, No. 1, 2017

\title{
SWITCHED RELUCTANCE MOTOR FOR A SURFACE LIFT DRIVE
}

\author{
Vasyl Tkachuk, Ihor Bilyakovskyy, Lidiya Kasha \\ Lviv Polytechnic National University, Ukraine \\ tkachuk@polynet.lviv.ua,ibilyakovsky@gmail.com,kashalidiya@gmail.com
}

(C) Tkachuk V., Bilyakovskyy I., Kasha L., 2017

Abstract:The basic equations of the method of the calculation of a switched reluctance motor (SRM) with a passive rotor and capacity energy storage (CES), which in the future is supposed to be used in a surface lift drive, are shown in the paper. The emphasis is placed on the peculiarities of the calculation of basic values, which then form the basis of the mathematical model of the design, which is implemented programmatically and using which the SRM for a surface lift drive was developed. Such a motor can successfully compete with traction collector motors for mechanical and regulating characteristics under the condition of higher reliability and smaller volume of an active part.

The design calculations are based on the recommendations taking into account the peculiarities of the design and the theory of electromagnetic energy conversion in electromechanical energy converters of the kind. The research results indicate the possibility of using the designed SRM in the electric drive of the surface lift.

Key words: switched reluctance motor, capacity energy storage, U-shaped stator construction, surface lift drive.

\section{Introduction}

An overhead ropeway is a hauling unit using continuously circulating steel cable loop for transporting goods in skips (ropeway conveyors), as well as passengers in cabins and open chairs (various aerial lifts), stretched between terminal stations and intermediate towers.

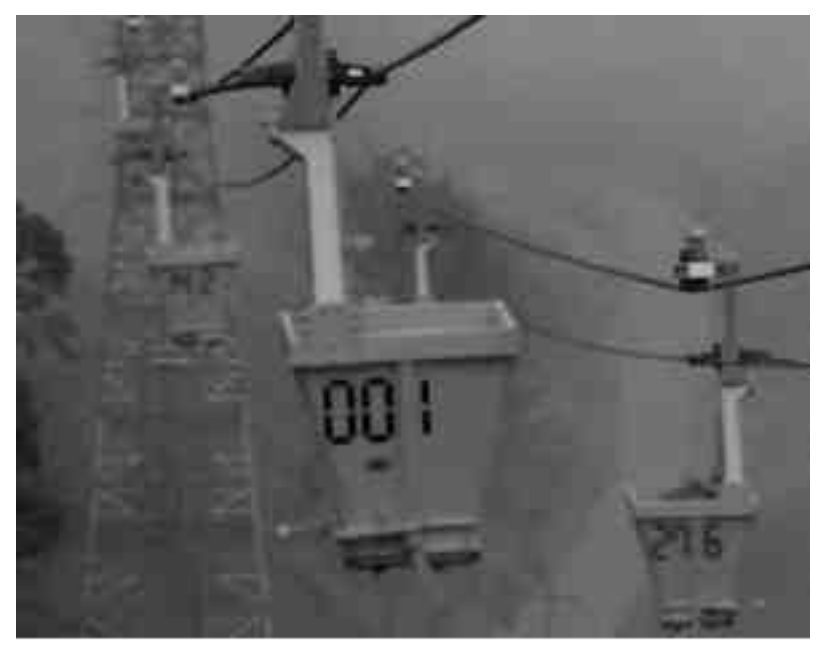

Fig. 1. Ropeway conveyor.
Aerial lifts are built in mountainous, rough and difficult terrain, as well as in cities and industrial communities for transit of mountains, valleys, steep slopes, and bodies of water. They create the most efficient and shortest transport links. They are also the basis of the transport infrastructure of ski resorts.

The history of aerial lifts began in the middle of the last century, after the creation of a cable from a steel wire (1834). First cable aerial lifts were ropeway conveyors.

Ropeway conveyors serve to transport mainly different bulk cargoes and are considered to be reliable, convenient and efficient. They are used in many branches of industry where compete successfully with automobile and railway means of transport.

Ropeway conveyors are divided into two main groups: bi-cable ropeway, or the cables having two different functions (carrying and pulling), and monocable ropeway with only one rope, which does the work of supporting and propelling simultaneously.

Bi-cable ropeways, in which the skips move on the rope attached to the steel supports and are pulled by a special hauling cable, are the most commonly used. On the one hand, such a ropeway is equipped with a drive station, and on the other with a dumping station.

The first passenger cableway was built in the Alps only in the 90's of the nineteenth century. It was a funicular, being a typeof cable railway.

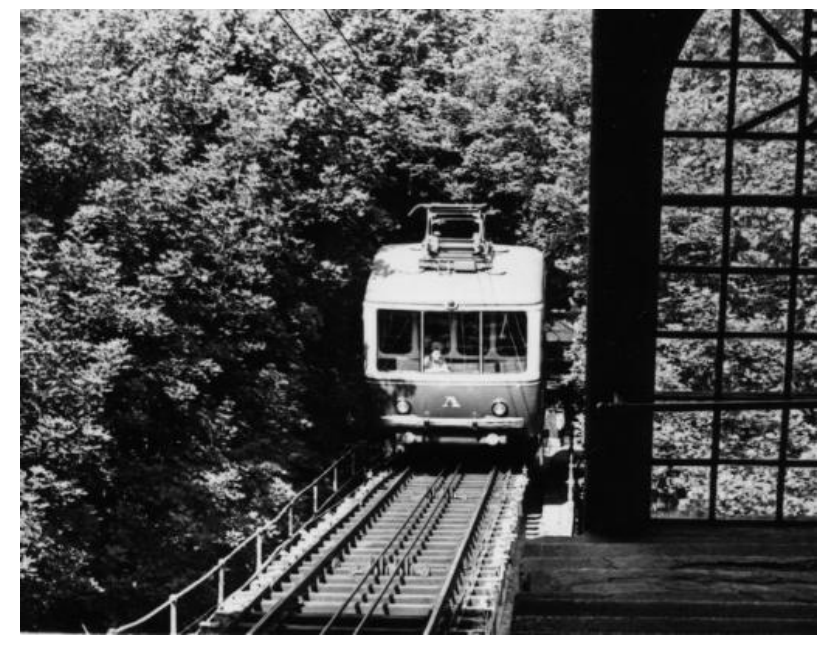

Fig. 2. Funicular. 
Cable railways were the main means of travelling in the mountains for forty years. However, the installation of funiculars is possible only on simple and smooth slopes. In addition, they are profitable only when used by a large number of tourists or mounted in large settlements. More convenient and versatile are cable aerial lifts, which are suspended and, so, detached from the ground.

It should be mentioned, that a few years ago, an attempt to build a cable car in Lviv Kaiserwald Park was made. This idea is not new for our city, since the first cable car operated in Lviv as far back as in 1894. At that time, the Crayova exhibition took place on the upper terrace of Stryiskyi Park. One of its attractions, which at the same time demonstrated the technology achievements of those days, was automated cableway, which lifted and lowered the cabin between the lower and upper terraces of the park. This cableway, which operated during the first month of the exhibition, moved at a speed of $1.3 \mathrm{~m} / \mathrm{s}$ and was about $200 \mathrm{~m}$ long.

The advantage of such a cable way is that it can be built anywhere, but it has also some serious disadvantages. One of themis the pendulum movement of a cabin when it is influenced by a strong lateral wind, and so a collision of the cabin with supports may occur during the operation. Moreover, such cableways are complex, expensive and can transport only few people [6].

After the Second World War, chairlifts and surface lifts were widely used in Europe, America and Japan. The simplest and cheapest type of cableway is a surface lift. They were very popularin the $20^{\text {th }}$ century. In most surface lifts, their T-bars, J-bars or platters are tightly attached to the rope. In 1933, a detachable surface lift was created. Its application allowed increasing speed and carrying capacity (up to 1000 skiers per hour) [4].

Ropetows are also widely used. They are light portable lifts, in which the rope is tensioned between the drive and reversing station (without intermediate supports) and handles can be attached to the rope to help grip [7]. It is designed to tow up the skiers, as well as to transport different skiing equipment on the snow slope. The advantages of such lifts are that they are easy to mount, so, if necessary, their location can be easily changed. These lifts are up to $350 \mathrm{~m}$ long and should be used for children and beginners along with so-called "magic carpets". In addition, they are easy to operate and environmentally friendly [4].

\section{Statement of the problem}

The analysis of recent literature sources and Internet resources suggests that conventional electric drives are used in electric drives of modern foreign cableways based on the prospective replacement of three-phase induction motors (ID) with variable-frequency control
(VFC) motors [4, 6] and, sometimes, synchronous motors [7]. However, quite often, three-phase IMis still used, requiring a significant power supply source to ensure the reliable startup of cable lifts with load.

The cable lifts are mounted mainly in difficult mountainous terrain,where it is not always possible to supply a three-phase source of sufficient power, which sometimes prevents the use of the IM (induction motors) with their multiple startup currents.

The switched reluctance motor (SRM) with capacitive energy storages is proposed to drive a surface lift that, in terms of mechanical and regulation characteristics, can successfully compete with traction collector motor for higher reliability and lower volume of the active part. In contrast to the IM, the velocity and energy indices of the SRM vary slightly during the voltage source fluctuations, but the natural mechanical characteristics of the SRM are practically the same as in the traction electric motors, which makes it possible to use SRM in the electric drive of the cablelift with limited power supply source.

The SRM is also a mechatronics system (Fig. 3, 4), which consist of an electromechanical converter (EMC) performing the function of actuator, rotor position sensor (RPS) and electronic switching system or electronic converter (EC). In many cases, EC is also used to control the rotation speed by the control system (CS), due to the presence of fully controlled power elements.

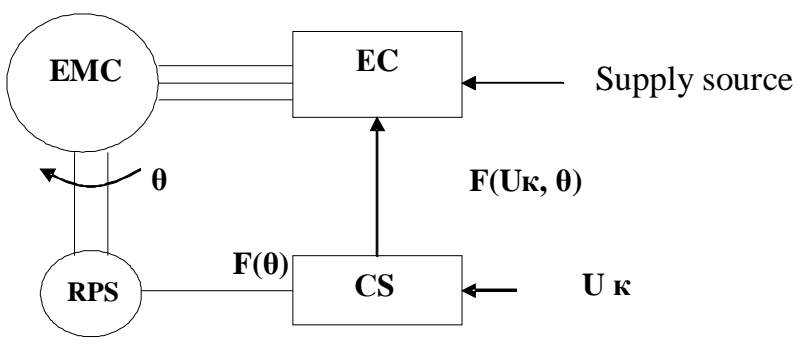

Fig. 3. Block diagram of SRM.

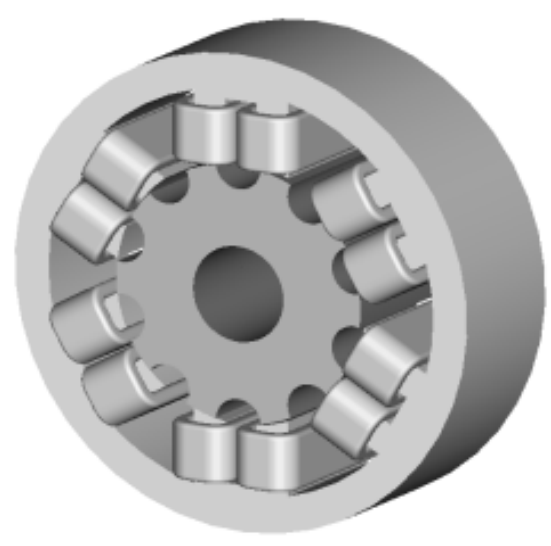

Fig. 4. Electromechanical converter of SRM. 
It is commonly known, that, in comparison with traction electric DC drive, SRM has a lot of constructive and technical-exploitation factors, the most important of which being contactlessness and reliability.

However, low energy performance of switched reluctance motors has long been a constraint on their widespread use. The value of the energy indices of the SRM is determined according to the energy stored in the electromagnetic field, which is to be dissipated to protect transistor switches from overvoltage during current switching in sections [10]. In [8] circuit design oftransistor inverters of SRM is proposed, which allow re-use of this energy for forced current switching in sections, while protecting power transistors from overvoltages.

The purpose of the work is to corroborate the possibility of using switched reluctance motors with capacitive energy storages for the electric drive of a surface lift.

\section{Results of computation simulation and its justification.}

The electromagnetic loads and the active zone of the signal sector of the rotor position sensor (RPS) are increased to improve the use of SRM. At the same time,at different time points a different number of sections are connected to the power supply, which causes significant pulsations of the supply current of the SRM, which is undesirable in the controlled electric drives.

Improving the energy data and reducing the current ripples of the power source of SRM allows creating a half-wave circuit with a parallel connection of the capacitor $[1,8]$. The circuit scheme of the SRM with a parallel capacitive energy storage (energy buffer) (CES) is shown in Fig. 5. Similarly, it is possible to increase the reliability of a SRM with parallel CES, replacing the individual transistor switches and diodes of the re-feed section with a common switch and a diode [8].The scheme will acquire the form, which is shown in Fig. 6. In this commutator, the control of a switch VT4 is carried out by the signals of RPS revealing the coincidence of the signals of adjacent channels.

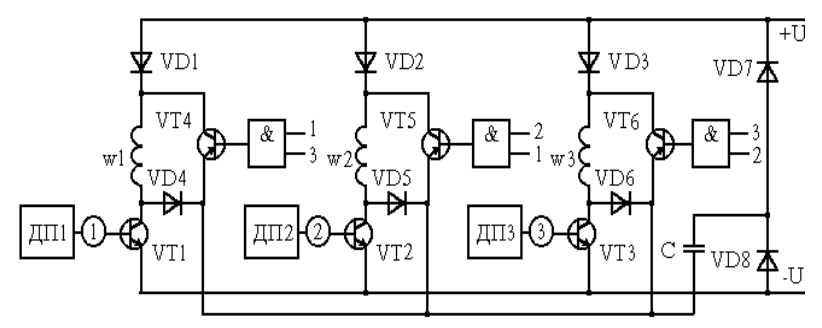

Fig. 5. Transistor commutator with parallel energy capacitors.

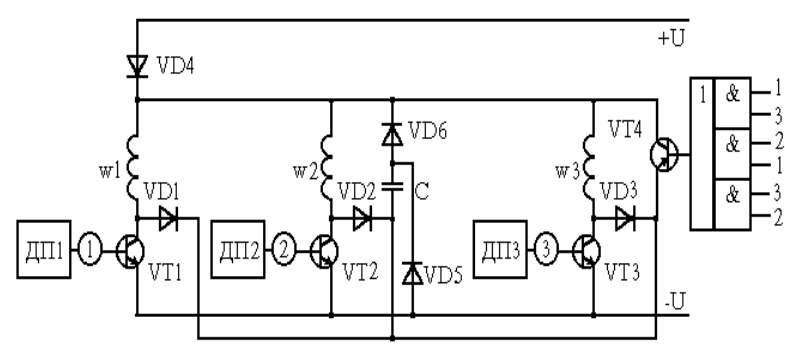

Fig. 6. Transistor commutator with parallel energy capacitors and general forcing circuit.

The capacitor is charged by the circuit through the diodes VD1 - VD3 and the diode VD4 (Fig. 7).

There is drastic decrease in current in the section and the capacitor charges to a voltage greater than the supply voltage.

A pseudo U-shaped stator construction (Fig. 4) is applied in such a switched reluctance motor. This construction provides extremely small electromagnetic communications between the sections, which increases the stability of electronic components and energy performance due to the smaller length of the magnetic force lines compared with the classical structure and, consequently, losses in steel [5]. And, in fact, the SRM with capacitive energy storage have practically the same energy performance as those with DC traction motor.

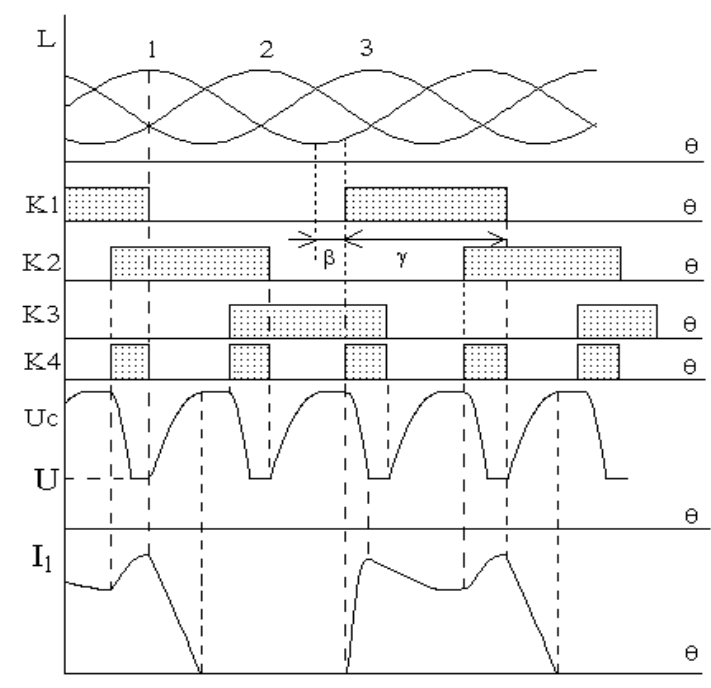

Fig. 7. Induction of phase, performance characteristic of switches, capacitor voltage and phase current in teta-function of SRM with parallel capacitor.

We substantiate the possibility of using SRM with the CES in the electric drive of the surface lift.

The expression for the mean value of the electromagnetic moment of the SRM [1]

$$
M_{C E P}=Z_{r} \frac{I_{c}^{2}}{4} \mu_{0} \frac{D \cdot l}{\delta} \alpha_{s} \frac{K_{L}}{K \mu} w_{z}(1-\cos \gamma),
$$


includes geometrical dimensions $\left(D, l, \delta, \alpha_{s}, z_{r}\right)$, data for windings $\left(w_{z}\right)$ and coefficients $\left(K_{L}, K_{\mu}\right)$ that give the possibility to analyze its value according to the structural parameters and to compare the SRM with other types of electric machines by the amount of electromagnetic moment created per unit volume. This comparison [5] shows that with identical diameters and lengths of rotor, a switched reluctance motorwithCES creates approximately the same electromagnetic moment as the traction DC motor, that is, in the sense of creating an electromagnetic moment, it can compete with it. Natural mechanical characteristics of both motors are practically the same.

One of the requirements for the electric drive is, as well, the possibility of electrodynamic braking. Among different breaking methods fo relectric motors, two methods are appropriate for SRM:

- breaking by excitation of one or more sections of the stator winding;

- reversing [10].

Cable lifts are usually made with one, and in some cases, two electric motors in a drive. In this scheme, the pulling forces from electric motors are transmitted to the gear unit of a driving wheel.

Typically, the technical characteristics of a surface lift show a maximum working speed of 4-6 km/h.

Thus, the power of pulling electric motor islimited to $30-80 \mathrm{~kW}$.

The design calculation of the SRM for the electric drive of the surface lift was carried out on the department of electric machines and apparatus of the computer-aided design system (CADS) of the switched reluctance motors with capacitive energy storages [2]. The system contains the main software, 16 subprogramms and data files, has an open structure and allows for extending and modernizing he tasks of the development of the SRM with CES. The subprogram prepares the necessary input data for conducting the investigation of the electromotive drive on the basis ofthe SRM with CES in the computer-aided research system (CARS) for such motors [3]. In order to ensure the possibility of the development of motors of higher power and voltages, appropriate changes were made in the CADS in advance.

Typical methods of developing the traditional types of electric machines are based on the choice of the order of electromagnetic loads, the experience of which for the SRM with CES being limited. The specified values need to be corrected accordingly. Therefore, the theory of electromechanical energy conversion is the basis for calculating the motor for the electric drive of the surface lift with the SRM with capacitive energy storage devices. As well, such design calculation is based on comparative analysis of the torque and electromagnetic loads of the SRM with CES and the traction direct current electric motor. In [1], the expressions for calculating the geometric dimensions of lamination stack of the SRM with the CES of the classic and pseudo-Ushaped constructions of stator are given. However, due to the lack of experience in the application of SRM with CES, it is not possible to use the practice of designing traditional types of electric machines by the method, in which values of independent variables are preset according to the previously developed machines of the same type and power. Therefore, the choice of independent parameters during the design calculation of switched reluctance motor is carried out on the base of the research results conducted at the Department of Electrical Machines and Apparatus.

At the same time, it is perceptible that for a construction with a pseudo-U-shaped stator the relation between number of stator and rotor teeth has the following form

$$
Z_{r}=Z_{s} \cdot \frac{2 \cdot m \pm 1}{2 \cdot m} ; Z_{s}=m \cdot q ; q=4,6,8 \ldots,
$$

where $m$ is a number of the SRM section.

Equation for the calculation of the external diameter of pseudo-U-shaped stator is

$$
D=2 \cdot \sqrt[3]{\frac{2 \cdot M \cdot\left(\gamma^{*}+\theta_{A}^{*}\right)}{(2 \cdot m-1) \cdot B_{\delta} \cdot A \cdot \pi \cdot \alpha_{s} \cdot K_{L} \cdot(1-\cos \gamma) \cdot \lambda}},
$$

where $B_{\delta}=\frac{I_{c} \cdot w_{z}}{K_{\mu} \cdot \delta} \cdot \mu_{0}$ is gap flux density for the position, when rotor and stator teeth coincide;

$$
A=\frac{2 \cdot I_{c} \cdot w_{z} \cdot q}{\pi \cdot D} \cdot\left(\gamma^{*}+\theta_{\hat{A}}^{*}\right) \text { is electric loading; }
$$

$\lambda=l / D$ is relative stator length;

$$
\gamma^{*}=\frac{\gamma \cdot m}{2 \cdot \pi} ; \theta_{\hat{A}}^{*}=t_{o} \cdot \frac{m \cdot z_{r}}{4 \cdot \pi} \cdot \omega \text { are relative values of }
$$
a commutating angle and firing angle, correspondingly.

The optimality criterion of the chosen variant was the mechanical characteristic and the maximum moment that the motor could develop. As a result of the design, a SRM, whose cross-section is shown in Fig. 8, has been obtained with the following parameters: nominal voltage supply after rectifier - $540 \mathrm{~V}$; useful power $-33 \mathrm{~kW}$; rotation speed $1500 \mathrm{rpm}$; efficiency $-77,2 \%$. 


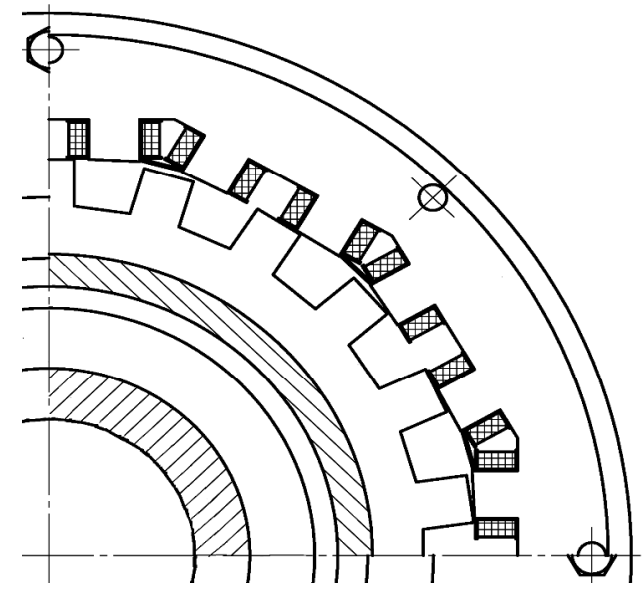

Fig. 8. Motor cross-section.

The motor was investigated with the use of computer-aided research system for the SRM with the capacitive energy storages developed at the Department of Electrical Machines of Lviv Polytechnic National University [3, 9]. The input data for such CARSis the output file, calculated using the designed system. Several variants of simulation of its operation in start-up and quasi-steady states at different loads were conducted.The mechanical characteristics of one of them are shown in Fig. 9. In the electric drive of the surface lift, two such motors are applied to replace the induction motor with powerof $65 \mathrm{~kW}$. They possess a total powerof $66 \mathrm{~kW}$ and rotational speed of $1430 \mathrm{rpm}$.

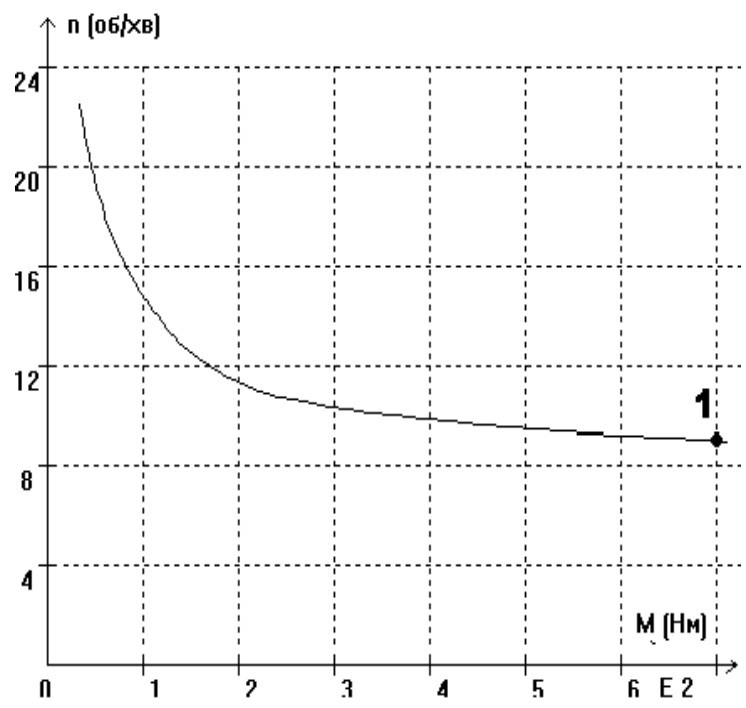

Fig. 9. Mechanical characteristic of designed SRM.

The results of calculations, which are based on known techniques used to obtain dynamic characteristics of the surface liftswith IM and on a given mechanical characteristic of the drive motor show that the electric drive, based onthe designed SRM, provides the required traction speed.

At the same time, the startup of the SRM is possible at considerablepowerdecrease, and the starting current practically does not exceed the nominal, unlike the induction motors.

\section{Conclusions}

1. SRM with capacitive energy storages has been proposed for the drive of the surface lift. It can successfully compete with traction collector motors because of its higher reliability and lower volume of the active part, thanks to its mechanical and regulation characteristics. Rapidity and energy performance of SRM slightly changed mains voltage fluctuation and load changes, unlike induction motors, as well as natural mechanical characteristics of switched reluctance motor are almost the same as in the traction motors, which enables the SRM to be usedin the electric cable extraction with limited network power.

2. The SRM circuits of the transistor inverters are proposed, which allow re-using stored energy, which was accumulating in the electromagnetic field during sections switching, for speed-up switching current in sections, while protecting the power switches from overvoltage, which significantly increased the energy performance of SRM.

3. Design calculations take into account the recommendations based on the design features and the theory of electromagnetic energy conversion. The design of the SRM for the electric drive of the cable surface lift was carried out with the use of a computer-aided design system (CADS) support developed for the switched reluctance motor with capacity energy storages.

4. The results of the research indicate the possibility of using such motors in the electric drive of a cable surface lift.

\section{References}

[1] V. Tkachuk, L. Kasha, and O. Greschuk. "Controlled switched reluctance motor with parallelcapacitor", Tehnichna elektrodynamika, vol. 3, p. 37-40, Ukraine, 2004. (Ukrainian)

[2] V.Tkachuk, "Subsystem of computer dialog design of a switched reluctance motor", Elektroenerhetychni ta elektromekhanichnisystemy, no. 340, p. 112-120, Lviv Polytechnic National University: Lviv, Ukraine, 1997. (Ukrainian)

[3] V. Tkachuk, "Subsystem of computer research of a switched reluctance motor", Tehnichna elektrodynamika, p. 180-187, Ukraine, 1998. (Ukrainian)

[4] Set of traction DC electric drive for electric transport, www.npfarsterm.ru (Russian)

[5] V. Tkachuk, I. Bilyakovskyy, and V. Haiduk, "Switched reluctance motor with high effisiency", 
Problemy avtomatyzovanoho elektropryvodu. Teoriya i practyka, p. 187-188, Ukraine, 2007. (Ukrainian)

[6] http://www.privod-news.ru/june_03/26-1.htm.

[7] http://www.orionmotor.narod.ru/trans.htm.

[8] V. Tkachuk and Yu. Osidach, "Transistor commutator with capacitive buffer of energy", Elektroenerhetychni ta elektromekhanichni systemy, no. 301, p. 115-122, Lviv Polytechnic National University: Lviv, Ukraine, 1996. (Ukrainian)

[9] V. Tkachuk, "Mathematical model of a switched reluctance motor for mean values", Elektroenerhetychni ta elektromekhanichni systemy, no. 301, p. 106-115, Lviv Polytechnic National University: Lviv, Ukraine, 1997. (Ukrainian)

[10] V. Tkachuk, L. Kasha, and I. Shapovalov, "Switched reluctance motor in a controlled electric drive", in Proc.VIIth International Conference «Perspective Technologies and Methods in MEMS Design» (MEMSTECH), p. 120-123, LvivPolyana, Ukraine, 2011.

\section{ВЕНТИЛЬНИЙ ДВИГУН ДЛЯ ЕЛЕКТРОПРИВОДУ КАНАТНОГО ВИТЯГУ}

Василь Ткачук, Ігор Біляковський, Лідія Каша

Подано основні формули методики розрахунку вентильних двигунів з пасивним ротором та $з$ ємнісними накопичувачами енергії, які надалі планується використовувати у приводах канатного витягу. Закцентовано увагу на особливостях розрахунку базових величин, які в подальшому утворюють основу математичної моделі проектування, що реалізована програмно та за допомогою якої спроектований двигун для приводу бугельного витягу. Такий двигун за механічною та регулювальними характеристиками може успішно конкурувати 3 тяговими колекторними двигунами, що використовуються у таких приводах, за умов вищої надійності і меншого об'єму активної частини. В основу проектного розрахунку покла- дено рекомендації, які грунтуються на особливостях конструкції та на теорії електромагнітного перетворення енергії у таких електромеханічних перетворювачах енергії. Результати досліджень свідчать про можливість використання спроектованого двигуна в електроприводі бугельного канатного витягу.

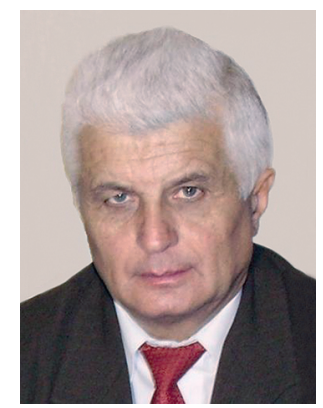

Vasyl Tkachuk - the Head of the Department of Electrical machines and apparatus at Lviv Polytechnic National University, Ukraine. Doctor of science, professor.

Research interests: theory of the electromechanical energy conversion in electromechanical inductor type converters.

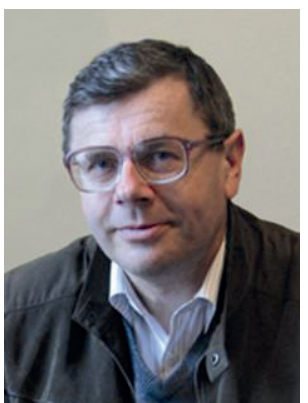

Ihor Bilyakovskyy - Ph.D., associate professor of the Department of Electrical machines and apparatuses at Lviv Polytechnic National University, Ukraine. Research interests: calculation, research of dynamic modes of switched reluctance motor.

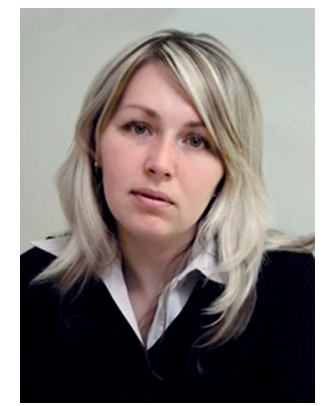

Lidiya Kasha - Ph.D., associate professor of the Department of Electrical machines and apparatuses at Lviv Polytechnic National University, Ukraine.

Research interests: mathematical modeling of processes in electromechanical energy converter; automated design of electrical machines; research and design of switched reluctance motor. 